\title{
Dietary Electrolytes And Their Effect On Hens Shell Quality During Heat Stress
}

\author{
B. Srigandono ${ }^{1}$, P. C.Harrison ${ }^{2}$, and K. C. Klassing ${ }^{3}$ \\ ${ }^{1}$ Faculty of Animal Agriculture, Diponegoro University, Tembalang New Campus, Semarang \\ ${ }^{2}$ Departement of Animal Sciences, University of Illinois, Urbana-Champaign, $I L$ \\ ${ }^{3}$ Departemen of Animal and Avian Sciences, University of California Davis, CA
}

\begin{abstract}
Abstrak
Suatu percobaan telah diadakan untuk mengevaluasi pengaruh perubahan kadar elektrolit dalam ransum $(\mathrm{Na}+\mathrm{K}-\mathrm{Cl})$ dengan suplementasi $\mathrm{NaHCO}_{3}, \mathrm{CaCl}_{2}$, atau $\mathrm{NaCl}$, terhadap kualitas cangkang telur pada ayam dalam suhu termonetral maupun dalam cekaman atau stres panas. Hasil penelitian ini menunjukkan bahwa pada periode termonetral, keseluruhan kualitas cangkang telur tidak terpengaruh oleh kadar $(\mathrm{Na}+\mathrm{K}$ - Cl) dalam kisaran 52 sampai 289 miliekivalen (meq) tiap kg ransum. Namun demikian, ayam yang yang ransumnya disuplementasi dengan $\mathrm{CaCl}_{2}$ dengan kelebihan cation sebesar 52 meq memperlihatkan keunggulan dalam kualitas cangkang telur, dalam masa cekaman panas. Kualitas cangkang yang ransumnya mengandung $\mathrm{CaCl}_{2}$ yang dianggap sebagai ransum yang paling baik, masih berada di bawah tingkatan kritis dengan resiko yang masih tinggi telur akan retak selama handling dan pengangkutan. Sumber karbonat lain untuk dikombinasikan dengan $\mathrm{CaCl}_{2}$, perlu dicari dan diselidiki lebih jauh. Kadar $\mathrm{Na}+\mathrm{K}-\mathrm{Cl}$ yang lebih rendah, sebaiknya digunakan dalam suasana cekaman panas, saat ayam mengalami keadaaan alkalosis pernafasan.
\end{abstract}

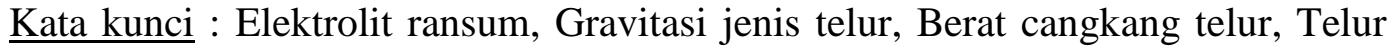
cangkang lunak, Cekaman panas.

\section{Introduction}

Several factors have been recognized to contribute to shell breakage from the point of lay to the later stages of processing and transportation to the consumers. The condition of a shell at the time of ovipositor can influence the incidence of shell breakage (Washburn, 1982). Other factors may include age of hens, stance, design of cage, floor density and frequency of egg gathering.

The most frequent observation of this problem is obviously encountered during the summer months when the ambient temperatures are high. Izat et al. (1985) suggested that eggs produced during the summer months contain shells with significantly less mass and thickness. They showed that during the summer months when the temperatures may reach $32.2^{\circ} \mathrm{C}$ inside the poultry house, shell thickness, shell weight, shell percentage, and specific gravity were lower $(\mathrm{p}<0.05)$ than during the fall and winter. Even though there is no estimate available on the financial loss, the situation in tropical regions of the world may be even worse since higher environmental temperatures usually occur over much longer periods.

Mogin (1970) suggested that acid-base balance was an essential factor influencing shell quality and even albumen quality of eggs. Since there is an interaction among major ions, Sauveur and Mogin (1978) proposed that for laying hens' diet, the optimum concentration of $\mathrm{Na}, \mathrm{K}$, and $\mathrm{Cl}$ cannot be determined indepen- 
dently but depends on the two others in the diet. They suggested that the value of $\mathrm{Na}+\mathrm{K}-\mathrm{Cl}$ in the diet should be maintained around 200 mill equivalent per $\mathrm{kg}$ for an optimum production level for laying hens.

It has been shown that a high environmental temperature results in a disturbance of cid-base balance called respiratory alkalosis because of the reduced blood $\mathrm{pCO}_{2}$ and $\mathrm{H}^{+}$from over ventilation (Lindsley and Burger, 1964). Harrison and Biellier (1967 proposed acid-base balance as a physiological factor which importantly contributes to egg shell strength. They found that within the first day of exposure to $35^{\circ} \mathrm{C}$, the specific gravity of egg decreased.

Numerous attempts have been made to improve shell quality and minimize shell breakage by using various compounds to alter the acidbase status of laying hens. Sodium bicarbonate was used in attempts to replenish the exhausted $\mathrm{CO}_{2}$, while $\mathrm{CaCl}_{2}$ was given to correct the acidbase status. However, the results are mixed and inconclusive.

The study was undertaken with the aim of understanding whether varying the dietary electrolyte levels with $\mathrm{NaHCO}_{3}, \mathrm{CaCl}_{2}$, and $\mathrm{NaCl}$ during heat stress affected the performance of hens.

\section{Material And Methods}

This study was conducted at the Animal Science Lab, University of Illinois, in a temperature-regulated environment $\left(35 \pm 4^{0} \mathrm{C}\right)$. Fifty-five week old individually caged Single Comb White Leghorn hens were used in this study.

Diets with different levels of sodium plus potassium minus chloide, $\mathrm{Na}+\mathrm{K}-\mathrm{Cl}$, namely $52,169,171$,
231, and 289 mill equivalent (meq) per kg feed (Table 2) were prepared.

Formulation of the diet was by the supplementation of the basal diet (Table 1) with either 0.5 or 1.0 percent $\mathrm{NaHCO}_{3}$ (Tables 2 and 3), 0.66 percent $\mathrm{CaCl}_{2}$ (Table 4) or 0.696 percent NaCL (Table 5). The dietary treatments were equal in calories and protein. Tables 3 and 5 were equimolar in sodium, while the tables 4 and 5 were equimolar in chloride. The composition of the basal diet, and the treatments are shown in Table 1. The experiment was divided into three consecutive periods:

1. Two weeks of constant 230C environmental temperature, which was considered a thermo neutral acclimation period.

2. Two weeks of constant $35 \pm 4^{0} \mathrm{C}$ environmental temperature, which was considered a heat stress period.

3. One week of constant $23^{\circ} \mathrm{C}$ environmental temperature, which was considered a thermo neutral recovery period.

Five dietary treatments were assigned to 160 experimental hens with treatment groups consisting of 32 hens each. Incandescent light of fivefoot candles intensity was provided 16 hours daily. Water and the appropriate experimental diet were supplied at libitum. Feed consumption was obtained on a weekly basis by calculating the difference between feed given and feed left in the feeder troughs.

Soft shell or membrane egg yields were recorded, specific gravity of eggs were also determined daily. To obtain shell weight and shell percentage, eggs were carefully broken to remove egg contents and the shells were dried for seven days at 
thermo neutral temperatures before being weighed individually.

Analysis of data was performed by SAS general Linear Model Statistical Package (Statistical Analysis System, 1982) on the Cyber - IBM System, University of Illinois. Treatment means were compared with the least significant difference method.

\section{Results}

The combined results of the three temperature periods of the experiment are summarized in Table 3. Tables 4,5,6 and 7 represent the results of separate analysis of each variables, namely soft shelled egg production, egg specific gravity, shell weight and shell percentage in each of the three periods of experiment.

\section{Soft Shelled Eggs}

The production of soft shelledeggs is closely related with the exposure of hens to a high environmental temperature as clearly shown in Table 4. Within the twoweek of heat stress, 49 soft shelledeggs were produced eith tripled the number of soft eggs collected for the same length of time of the thermo neutral period. The largest number of soft shelled-eggs (a total of 15) was obtained from the birds give 1.0 percent $\mathrm{NaHCO}_{3}$ on shell quality especially when the birds were exposed to a hot environment. However, the lower ( 0.5 percent $)$ level $\mathrm{NaHCO}_{3}$ resulted in the fewest number (7) of soft shelled-eggs.

A slow relief from the occurrence of soft-shelled egg production appeared in all treatments, as evidence by the number of soft shelled-egg within the one-week period, after the environental temperature returned to the thermo neutrality.

\section{Egg specific gravity}

The result of this study showed that the dietary treatments did not affect the specific gravity of egg produced (Table 3 ). This fact was also true within each of the individual periods, as summarized in Table 5.

The specific gravity of eggs during the hot period of the experiment was lower $(p<0.01)$ than those eggs from the thermo neural periods treatments within this period. There was no interaction between dietary electrolyte and environmental temperature on specific gravity of the eggs.

A complete recovery from a heat-induced reduction in specific gravity was accomplished by all treatments within the last week of thermo neutrality when the room temperature was returned at $23^{0} \mathrm{C}$.

\section{Shell Weight and Shell Percentage}

Table 3 of combined period; show the data of shell weight and shell percentage. From the combined periods of the experiment (Table 3), it is clearly shown that $\mathrm{CaCl}_{2}$ and $\mathrm{NaCl}$ supplementation in the diets resulted in heavier shells (5.18 and 5.21 g) and higher shell to egg weight percentages. During the first acclimation thermo neutral period, the $\mathrm{CaCl}_{2}$ and $\mathrm{NaCl}$ groups had larger shell weights $(5.75$ and $5.70 \mathrm{~g})$ and shell percentages (9.02 and 8.99 percent as shown in Tables 6 and 7).

This situation continued during the heat stress (Tables 6 and 7), which were 4.41 and $4.45 \mathrm{~g}$ as well as 7.65 and 7.47 percent. The reduction in shell weight and shell percentage was a general phenomenon that was observed in all treatments during the imposition of high environmental temperature. 
A dramatic recovery from this reduction was shown in all treatments, when the environmental temperature was returned to the thermo neutrality. An average of $5.43 \mathrm{~g}$ of shell was produced by the $\mathrm{CaCl}_{2}$ group within one week of recovery with the highest shell percentage of 9.10 percent (Tables 6 and 7).

Table 1. Composition of Basal Diet

\begin{tabular}{|c|c|}
\hline Ingredient & $\%$ \\
\hline Corn & 69.30 \\
\hline Soybean meal ( $48 \%$ Crude protein) & 18.00 \\
\hline Meat bone meat & 2.50 \\
\hline Limestone & 8.25 \\
\hline Dical-PO $\mathrm{PO}_{4}$ & 1.25 \\
\hline $\mathrm{NaCl}$ & 0.40 \\
\hline Vitamin mix $^{\mathrm{a}}$ & 0.25 \\
\hline $\mathrm{MnSO}_{4}$ & 0.05 \\
\hline Total & 100.00 \\
\hline Calculated : Crude protein $(\%)$ & 16.00 \\
\hline Metabolically energy $(\mathrm{Kcal} / \mathrm{kg})$ & 2900 \\
\hline $\mathrm{Na}^{+}+\mathrm{K}^{+}-\mathrm{Cl}^{-}(\mathrm{meq} / \mathrm{kg})$ & 169 \\
\hline
\end{tabular}

Table 2. Treatment Composition

\begin{tabular}{llc}
\hline \multicolumn{1}{c}{ Treatment $^{\mathrm{a}}$} & Calculated $^{+}+\mathrm{K}^{+}-\mathrm{Cl}^{-}$ \\
\hline & & $\mathrm{Meq} / \mathrm{kg}$ \\
1. & Basal diet (B) & 169 \\
2. & $\mathrm{B}+0.5 \% \mathrm{NaHCO}_{3}$ & 231 \\
3. & $\mathrm{B}+1.0 \% \mathrm{NaHCO}_{3}$ & 289 \\
4. & $\mathrm{B}+0.66 \% \mathrm{CaCl}_{2}$ & 52 \\
5. & $\mathrm{B}+0.696 \% \mathrm{NaCl}$ & 171 \\
\hline
\end{tabular}

${ }^{a} \mathrm{NaHCO}_{3}, \mathrm{CaCl}_{2}$ or $\mathrm{NaCl}$ was added in place of corn.

Table 3. Effects of Treatments on Egg Shell Quality During the Three Combined Periods of Experiment

\begin{tabular}{lcccccc}
\hline & \multicolumn{3}{c}{ Treatment \& Meq Caution Excess } & \multicolumn{2}{c}{ Pooled } \\
Shell Quality Variable & $\mathrm{B}$ & $\mathrm{B}+0.5 \%$ & $\mathrm{~B}+1.0 \%$ & $\mathrm{~B}+0.66 \%$ & $\mathrm{~B}+0.696 \%$ \\
& (Basal) & $\mathrm{NaHCO}_{3}$ & $\mathrm{NaHCO}_{3}$ & $\mathrm{CaCl}_{2}$ & $\mathrm{NaCl}$ \\
\hline Cation-Anion (meq/kg) & 169 & 231 & 289 & 52 & 171 \\
Soft Shell Egg & 17 & 9 & 27 & 15 & 14 & \\
Specific gravity & 1.0726 & 1.0725 & 1.0735 & 1.0744 & 1.0745 & 0.0017 \\
Shell Weight (g) & 4.82 & 4.82 & 4.96 & 5.18 & 5.21 & 0.38 \\
Shell percentage (\%) & 8.06 & 8.12 & 8.31 & 8.48 & 8.30 & 0.65 \\
\hline
\end{tabular}

a,b Means within a row with different superscripts differ statistically $(\mathrm{p}<0.05)$ 
Table 4. Effects on Treatment on The Number of Soft Shelled-eggs Production in Each Period.

\begin{tabular}{|c|c|c|c|c|c|c|c|}
\hline \multicolumn{2}{|r|}{ Treatment } & B & $\mathrm{B}+0.5 \%$ & $\mathrm{~B}+1.0 \%$ & $\mathrm{~B}+0.66 \%$ & $\mathrm{~B}+0.696 \%$ & $\Gamma$ \\
\hline \multirow{5}{*}{$\Xi$} & Caution-Anion (meq $/ \mathrm{kg})$ & 169 & 231 & 289 & 52 & 17 & \\
\hline & Thermo neutral acclimation & 3 & 2 & 7 & 1 & 3 & 16 \\
\hline & Heat Stress & 11 & 7 & 15 & 9 & 7 & 49 \\
\hline & Thermo neutral recovery & 3 & 0 & 5 & 5 & 4 & 17 \\
\hline & Combined & 17 & 9 & 27 & 15 & 14 & \\
\hline
\end{tabular}

a, b Means with a row with different superscripts differ statistically $(\mathrm{p}<0.05)$

Table 5. Effects of Thermal Treatment on Egg Specific Gravity in Each Period

\begin{tabular}{|c|c|c|c|c|c|c|}
\hline & \multirow{2}{*}{$\begin{array}{c}\text { Treatment } \\
\text { Caution-Anion }(\mathrm{meq} / \mathrm{kg})\end{array}$} & $\begin{array}{c}\text { B } \\
\text { (Basal) }\end{array}$ & $\begin{array}{l}\mathrm{B}+0.5 \% \\
\mathrm{NaHCO}_{3}\end{array}$ & $\begin{array}{l}\mathrm{B}+1.0 \% \\
\mathrm{NaHCO}_{3}\end{array}$ & $\begin{array}{c}\mathrm{B}+0.66 \% \\
\mathrm{CaCl}_{2}\end{array}$ & $\begin{array}{c}\mathrm{B}+0.696 \% \\
\mathrm{NaCl}\end{array}$ \\
\hline & & 169 & 231 & 289 & 52 & 171 \\
\hline \multirow{4}{*}{$\cdot \frac{8}{\square}$} & Thermo neutral acclimation & 1.0753 & 1.0758 & 1.0750 & 1.0781 & 1.0782 \\
\hline & Heat Stress & 1.0655 & 1.0643 & 1.0656 & 1.0661 & 1.0661 \\
\hline & Thermo neutral recovery & 1.0769 & 1.0766 & 1.0802 & 1.0798 & 1.0782 \\
\hline & Combined & 1.0726 & 1.0725 & 1.0735 & 1.0744 & 1.0745 \\
\hline
\end{tabular}

a,b Means within a row with different superscripts differ statistically $(\mathrm{p}<0.05)$

Table 6. Effects of Thermal Treatment on Egg Shell Weight (g) in Each Period

\begin{tabular}{lccccc}
\hline \multirow{2}{*}{$\begin{array}{c}\text { Treatment } \\
\text { Cation-Anion (meq/kg) }\end{array}$} & $\begin{array}{c}\mathrm{B} \\
\text { (Basal) }\end{array}$ & $\begin{array}{c}\mathrm{B}+0.5 \% \\
\mathrm{NaHCO}_{3}\end{array}$ & $\begin{array}{c}\mathrm{B}+1.0 \% \\
\mathrm{NaHCO}_{3}\end{array}$ & $\begin{array}{c}\mathrm{B}+0.66 \% \\
\mathrm{CaCl}_{2}\end{array}$ & $\begin{array}{l}\mathrm{B}+0.696 \% \\
\mathrm{NaCl}\end{array}$ \\
\cline { 2 - 6 } & 169 & 231 & 289 & 52 & 171 \\
\hline \multirow{2}{*}{$\cdot \begin{array}{c}\text { Thermoneutral acclimation } \\
\text { Heat Stress }\end{array}$} & 5.37 & 5.46 & 5.42 & 5.75 & 5.70 \\
Thermoneutral recovery & 4.18 & 4.10 & 4.26 & 4.41 & 4.45 \\
Combined & 4.92 & 4.96 & 5.21 & 5.43 & 5.30 \\
\hline
\end{tabular}

a,b Means within a row with different superscripts differ statistically $(\mathrm{p}<0.05)$

Table 7. Effects of Thermal Treatment on Egg Shell Percentage (\%) in Each Period

\begin{tabular}{lccccc}
\hline \multirow{2}{*}{$\begin{array}{c}\text { Treatment } \\
\text { Cation-Anion (meq/kg) }\end{array}$} & $\begin{array}{c}\mathrm{B} \\
(\mathrm{Basal})\end{array}$ & $\begin{array}{c}\mathrm{B}+0.5 \% \\
\mathrm{NaHCO}_{3}\end{array}$ & $\begin{array}{c}\mathrm{B}+1.0 \% \\
\mathrm{NaHCO}_{3}\end{array}$ & $\begin{array}{c}\mathrm{B}+0.66 \% \\
\mathrm{CaCl}_{2}\end{array}$ & \multicolumn{2}{c}{$\mathrm{B}+0.696 \%$} \\
\cline { 2 - 6 } & 169 & 231 & 289 & 52 & 171 \\
\hline Thermoneutral acclimation & 8.61 & 8.71 & 8.62 & 9.02 & 8.99 \\
.$\overline{0}$ Heat Stress & 7.18 & 7.12 & 7.17 & 7.65 & 7.47 \\
Thermoneutral recovery & 8.75 & 8.60 & 8.15 & 9.10 & 8.97 \\
Combined & 8.06 & 8.12 & 8.31 & 8.48 & 8.30 \\
\hline
\end{tabular}

a,b Means within a row with different superscripts differ statistically $(\mathrm{p}<0.05)$

\section{Discussions}

The result of this study indicated that a two-week exposure to a constant hot temperature of $35 \pm 4^{0} \mathrm{C}$, severely depressed the overall performance of laying hens, including the production of soft-shelled eggs, egg specific gravity, shell weight, and shell percentage. These results are compatible with many previous studies. The occurrence of soft-shelled 
eggs or membrane eggs was considerably higher during the heat stress period compared to the thermo neutral period.

The diet supplemented with 0.66 percent $\mathrm{CaCl}_{2}$ seems to be superior for shell quality; while the 1.0 percent $\mathrm{NaHCO}_{3}$ added diet resulted in a slightly lower eggshell quality. The metabolic alkalosis, which could be caused from the inclusion of $\mathrm{NAHCO}_{3}$ in this diet, might explain this phenomenon. The works of Bottje and Harrison (1985) clearly demonstrated that the infusion of a two percent $\mathrm{NAHCO}_{3}$ solution into cockerels' crop, increased blood $\mathrm{pH}$ throughout both the thermo neutral and heat stress periods. Although the sodium bicarbonate concentration presently used in this experiment was not as high as the infused by Bottje and Harrison (1985), a chronic two week ingestion of the $\mathrm{NAHCO}_{3}$ containing diet might be enough to shift the acid base balance in the body toward alkalosis and result in the poor egg shell quality produced by the birds given the $\mathrm{NAHCO}_{3}$ supplemented diet.

These findings support preious researchers (Cox and Balloun 1968; Connor and Arnold, 1972; Ernst et al., 1975) who found that there was no improvement on eggshell quality from feeding $\mathrm{NAHCO}_{3}$ to laying hens. In some cases $\mathrm{NAHCO}_{3}$ was even detrimental to egg production and specific gravity (Cox and Balloun, 1968). Ferguson et al. (1974) and Ernst. (1975) Likewise noted that there was no beneficial effects from feeding 0.5 or 1.0 percent $\mathrm{NAHCO}_{3}$ to caged layers, while latif and Quisenberry (1968) reported only small and non significant improvement in shell thickness and specific gravity when either 0.25 or
0.50 percent $\mathrm{NAHCO}_{3}$ was added to pullets' diet. A more recent study, however, showed that including $\mathrm{NAHCO}_{3}$ in the diet appeared to improve shell quality, provided that the phosphorus level in the diet was low (Britton and Zumbado, 1984).

The relative ion concentration in the diet is important to note when various biological responses of $\mathrm{NAHCO}_{3}$ including in the diets are considered. One percent $\mathrm{NAHCO}_{3}$ supplementation used in other study was the diet with a 289 meq caution excess per $\mathrm{kg}$, and therefore should be metabolically very alkaline. A continuous ingestion of this diet would rapidly shift the acid-base balance toward alkalosis.

$\mathrm{CaCl}_{2}$ inclusion is proposed to produce acidosis because of the differential absorption of $\mathrm{Ca}^{2+}$ and $\mathrm{Cl}^{-}$ and the elimination of base excess (Mogin, 1981). However, the hens receiving 0.66 percent $\mathrm{CaCl}_{2}$ in the diet, which was considered as an acid diet (contained 52 meq cation excess per $\mathrm{kg}$ ), was able to maintain a better shell quality. These result appeared to be different from those described by caustic (1984) who indicated that shell thickness and shell strength were significantly decreased by high dietary chloride (0.90 percent $\mathrm{Cl}$ ) added as $\mathrm{CaCl}_{2}$. This different response would be due, in part, to the lower $\mathrm{CaCl}_{2}$ level used in the present study (which was only 0.66 percent $\mathrm{CaCl}_{2}$ ).

The following reactions are likely to occur in the gut and plasma after the ingestion and absorption of $\mathrm{CaCl}_{2}$.

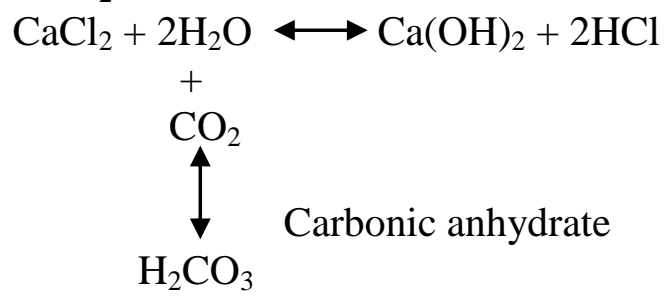




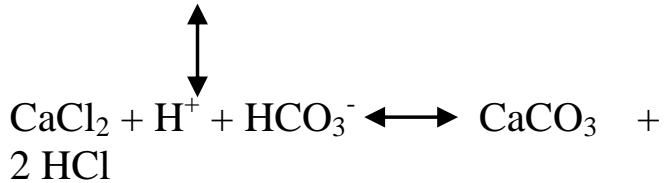

Even though in acid stomach conditions the reaction equilibrium should be to the left, the formation of $\mathrm{Ca}(\mathrm{OH})_{2}$ as a more soluble compound may increase the $\mathrm{Ca}^{2+}$ in the blood which is readily available for shell synthesis. This might explain the fact that dietary $\mathrm{CaCl}_{2}$ resulted in higher shell weight and shell percentage during the thermo neutrality. However, larger amount of $\mathrm{CaCl}_{2}$ could stimulate the formation of $\mathrm{CaCO}_{3}$, which is poorly absorbed, resulting in a lower shell quality.

During the heat stress, diet with $\mathrm{NaHCO}_{3}$ supplementation resulted in decreased shell quality as shown by the lower value of egg specific gravity, shell weight and shell percentage (Tables 5, 6, and 7). In addition, the higher (1.0 percent) $\mathrm{NaHCO}_{3}$ diet also resulted in largest number 15 of soft shelled-eggs in this period (Table 4). Since the NaHCO3 receiving hens laid most of the soft shelled-eggs and these very poor shelled-eggs could not be used in the shell quality evaluations, the difference in shell quality among the dietary treatments may actually be larger than reported. The ingestion of the 1.0 percent $\mathrm{NaHCO}_{3}$ diet (contained 289 meq cation excess per $\mathrm{kg}$ ), as mentioned in the thermo neutral discussions, would shift the animal's system toward a metabolic alkalosis. Since the birds were developing a respiratory alkalosis condition during thermoregulatory panting, the combination of respiratory alkalosis with the ingestion of an alkaline diet would be adding to the severity of alkalosis.
In the study reported herein, the cause for the $\mathrm{CaCl}_{2}$ supplemented diet to maintain better shell quality was not definitely established. This would be caused by partial $\mathrm{Ca}^{2+}$ availability, provided as $\mathrm{CaCl}_{2}$, and the acidogenic action of $\mathrm{CaCl}_{2}$ when the birds were in a respiratory alkalotic condition.

The fact that the $\mathrm{CaCl}_{2}$ added diet was a relatively acid diet (contained $52 \mathrm{meq}$ cation excess per $\mathrm{kg}$ ), is interesting to note, since Mogin (1970) suggested the value around 200 meq per $\mathrm{kg}$ is optimum for laying hens performance. Stevenson (1983), however, demonstrated that a range from 137 to 245 meq per $\mathrm{kg}$ did not result in any difference on laying hens' performance. More recently, Charles et al. (1985) confirmed that unceasing cation excess from 215 to 240 meq per $\mathrm{kg}$ diet, increased $(\mathrm{p}<0.05)$ shell quality.

Bottje and Harrison (1985) showed that an infusion of 3.5 percent $\mathrm{CaCl}_{2}$ solution into cockerel's crops decreased the blood $\mathrm{pH}$ during a heat stress exposure. This acid-base shift might not by as great when $\mathrm{CaCl}_{2}$ is in much lower concentrations, as used in the present experimental diet.

This may explain the beneficial response to $\mathrm{CaCl}_{2}$ observed in this study. Assuming a $55 \mathrm{~g}$ daily feed intake during heat stress, the total daily $\mathrm{CaCl}_{2}$ ingestion would be $66 / 100$ $\mathrm{x} 55 \mathrm{~g}=0.363 \mathrm{~g}$ per hen. This is a small amount, which might not appreciably create an acid-base imbalance and decreased carbonate level in the body.

The overall results of this experiment again clearly demonstrated the detrimental effects of hot environments on eggshell quality regardless of the dietary supplements. Even the quality of shells from the hens given $\mathrm{CaCl}_{2}$ in the diet which 
was considered as the most beneficial treatment, was still below the critical level of shell quality with a high risk of breakage during mechanical handling and transportation.

If the $\mathrm{Ca}^{2+}$ availability for absorption increased due to $\mathrm{CaCl}_{2}$ ingestion, a better $\mathrm{CaCO}_{3}$ formation for shell synthesis might occur if an additional supply of carbonate could be available. However, efforts to furnish carbonate by additing $\mathrm{NaHCO}_{3}$ in the diets resulted in a contradictory if not additional deleterious effects. These effects were possibly results of exacerbating the alkalosis due to panting. Therefore, other source which might supply carbonate needs to be used in combination with $\mathrm{CaCl}_{2}$ which in turn can supply $\mathrm{CaCO}_{3}$ constituents more available for egg shell formation. These deserve further investigation.

\section{Conclusion}

During thermo neutrality, the overall quality of laying hens was not affected by the levels of $(\mathrm{Na}=\mathrm{K}-\mathrm{Cl})$ in the range of 52 to 289 milliequibalent per $\mathrm{kg}$ diet. However, hens given the $\mathrm{CaCl}_{2}$ supplemented diet, with the cation excess of $52 \mathrm{meq}$ showed superiority in shell quality performance during exposed to heat stress. Other sources, which might able to supply carbonate needs to be used in combination with $\mathrm{CaCl}_{2}$, deserves further investigation. A lower dietary $\mathrm{Na}+\mathrm{K}-\mathrm{Cl}$ might be beneficial in hot environment when the birds were in a respiratory alkalotic condition.

\section{References}

Austic,R. E. 1984 Excess dietary chloride depresses egg shell quality. Poultry Sci. 63:17773-1777.
Bottje, W.G. and P.C. Harrison. 1985. The effect of tap water, carbonated water, sodium bicarbonate, and calcium chloride on blood acid-base in cockerels subjected to heat stress. Poultry Sci. 64:107113.

Charless, O.W.,M.N. Makled and S. Duke. 1985. Acid-base interrelationships in Leghorn hens. Poultry Sci. 64 (Suplement 1): 77 (Abstract).

Connor, J.K. and K.J. Arnold. 1972. The effects of calcium, fat and sodium bicarbonate on egg shell strength. Austr, J. Exp. Agric.Husb. 12:146.

Harrison, P.C. and H.V. Biellier. 1967. Variations in physiological rate functions of the domestic fowl subjected abrupt changes in environmental temperature. Poultry sci 46:1269.

Izat, A.L., F.A. Gardner and D.B. Mellor. 1985. Effects of age of birds and seasons of the year on egg quality. No.1 Shell quality. Poultry Sci: 64: 1900-1906.

Lindsley, J.G. and R. E. Burger. 1964. Respiratory and cardiac vascular responses in the hyperthermic domestic cock. Poultry Sci. 43:291.

Mongin, P. 1970. The role of the carbonate ion in egg shell formation. Page 99 in Proc. Cornell Nutr. Conf, Cornell Univ., Ithaca, N.Y. 
Mongin, P. 1981. Recent advances in dietary anion-cation balance : Application in poultry. Proc. Nutr. Soc. 40:285

SAS. 1982. User's Guide. Stat. Anal. System Inst., Cary, NC.

Sauveur, B. and P. Mongin. 1978. Interrelation between dietary concentrations of sodium, potassium and chloride in laying hens. Br. Poultry Science, 19:475-485

Staten, F.E. and P.C. Harrison. 1984. Renal compensation for high environmental temperature induced acid-base disturbances in single Comb
White Leghorn hens. Poltry Sci. 63 (Supplement 1) : 1888 (Abstract).

Stevenson, M.H. 1983. The effect on egg production of adding sodium bicarbonate and potassium carbonate to a practical type layers diet. J. Sci. Food Agric. 34 : 13581360.

Washburn, K.W. 1982. Incidence, cause and prevention of egg shell breakage in commercial production. Poultry Sci. 61: 2005-2012.

\section{Alamat Korespondensi: Bambang Srigandono Lektor Kepala/ Dekan Fakultas Peternakan Universitas Diponegoro Semarang.}

Artikel diterima: 5 September 2005, disetujui: 29 Mei 2006 